\title{
Penerapan model advance organizer menggunakan Macromedia Flash untuk meningkatkan pemahanan konsep Siswa SMA Negeri 3 Bireuen
}

\author{
Nanda Safarati \\ Pendidikan Fisika, Universitas Almuslim, Indonesia \\ Surat-e: safaratinanda@gmail.com \\ Rahma \\ Pendidikan Fisika, Universitas Almuslim, Indonesia \\ Surat-e: rahma@umuslim.ac.id
}

\begin{abstract}
Abstrak. Penelitian ini bertujuan untuk meningkatkan pemahaman konsep siswa SMA 3 Bireuen pada materi fluida. Penelitian ini dilakukan menggunakan pendekatan kuantitatif, jenis penelitian quasi eksperimen. Teknik pengambilan sampel menggunakan cluster random sampling, terpilih dua kelas sebagai kelas eksperimen dan kontrol. Sampel penelitian terdiri dari 2 kelas yang dipilih secara acak dengan teknik cluster random sampling. Desain penelitian menggunakan desain two group pretes-postes design. Hasil penelitian ini adalah: model pembelajaran advance organizer menggunakan macromedia flash dapat meningkatkan pemahaman konsep siswa sehingga hasil belajar siswa meningkat. Hal ini dibuktikan dengan data analisis siswa perolehan nilai rata-rata posttest kelas kontrol adalah 73,33 dan nilai ratarata posttest kelas eksperimen adalah 80,00 . Hal ini menunjukkan bahwa pemahaman konsep siswa terjadi peningkatan dengan model advance organizer menggunakan Macromedia Flash.
\end{abstract}

Kata kunci: Advance Organizer, Macromedia Flash, Pemahaman Konsep

\begin{abstract}
This study aims to improve the understanding of the concept of Bireuen 3 High School students on fluid material. This research was conducted using a quantitative approach, a quasi-experimental type of research. The sampling technique uses cluster random sampling, two classes are selected as the experimental and control classes. The research sample consisted of 2 classes chosen randomly by cluster random sampling technique. The research design uses two group pretest-posttest design. The results of this study are: advance organizer learning models using macromedia flash can improve student understanding of concepts so that student learning outcomes improve. This is evidenced by the students' analysis of the acquisition of the average value of the posttest score of the control class is 73.33 and the average posttest score of the experimental class is 80,00 . This shows that the understanding of student concepts has increased with the advanced organizer model using Macromedia Flash.
\end{abstract}

Keywords: Advanced Organizer, Macromedia Flash, Understanding Concepts

\section{Pendahuluan}

Pendidikan memiliki peran dan pengaruh positif terhadap segala bidang kehidupan dan perkembangan manusia. Pengaruh pendidikan dapat dirasakan secara langsung dalam perkembangan kehidupan masyarakat, kelompok dan individu. Kualitas pendidikan sangat menentukan besarnya pengaruh pendidikan dalam kehidupan [1].

Proses dari serangkaian kegiatan pembelajaran merupakan ruang lingkup dari pendidikan, salah satunya adalah pembelajaran sains. Fisika merupakan salah satu cabang sains yang mendasari perkembangan teknologi saat ini. Dengan belajar fisika, siswa akan mengetahui dan memahami fenomena alam semesta dan mampu menerapkan konsep-konsep fisika dengan metode ilmiah yang melibatkan keterampilan berpikir agar dapat memecahkan masalah dalam kehidupan sehari-hari, serta dapat meningkatkan kesadaran IPTEK, kelestarian lingkungan dan kebanggaan nasional. Young \& Freedman [2] menyatakan bahwa "fisika adalah salah satu ilmu yang paling mendasar dari ilmu pengetahuan. Fisika adalah proses yang membawa kita pada prinsip- 
prinsip umum yang mendeskripsikan bagaimana perilaku dunia fisik". Selain itu yang paling penting adalah proses dalam pembelajaran itu sendiri. Keberhasilan dalam pembelajaran dapat ditingkatkan apabila proses pembelajaran berlangsung secara efektif dan kondusif dengan menggunakan metode, strategi dan model pembelajaran yang tepat.

Berdasarkan observasi peneliti di SMA Negeri 3 Bireuen, pembelajaran fisika yang selama ini diajarkan masih bersifat konvensional. Proses pembelajaran fisika yang disajikan hanya memberikan pemahaman tentang menghitung persamaan-persamaan matematika untuk memecahkan soal-soal dalam pelajaran fisika, tanpa memperhatikan pemahaman konsep siswa terhadap fisika itu sendiri. Informasi yang didapatkan siswa hanya sebatas angka-angka da perhitungan matematis, akibatnya siswa merasa bosan dan tidak menyukai pelajaran fisika. Penggunaan laboratorium dan media pembelajaran masih sangat jarang dilakukan, sehingga tidak jarang kita melihat siswa bersikap pasif, hanya menjadi pembaca, bersikap sebagai pendengar, mencatat materi yang diberikan oleh guru dan menyelesaikan tugas/soal yang telah dipelajari dengan panduan contoh soal yang telah diberikan oleh guru, sehingga siswa hanya menggunakan keterampilan berpikir mereka untuk menjawab soal-soal fisika yang diberikan oleh guru tanpa memahami bahwa sebenarnya terdapat konsepkonsep yang harus diketahui didalam pembelajaran fisika itu sendiri.

Salah satu model yang dapat diterapkan dalam situasi ini adalah model pembelajaran advance organizer. Model pembelajaran dirancang untuk memperkuat struktur kognitif siswa atau pengetahuan siswa tentang pembelajaran dan bagaimana mengelola, memperjelas dan memelihara pengetahuan tersebut dengan baik [3]. Menurut Ausubel [3], faktor utama yang menentukan apakah materi baru akan bermanfaat atau tidak dan bagaimana pengetahuan yang baru itu dapat diperoleh dan dipertahankan dengan baik adalah struktur kognitif yang ada dalam diri seseorang. Sebelum menyajikan materi baru secara efektif, maka stabilitas dan kejelasan struktur siswa harus ditingkatkan. Model pembelajaran advance organizer dapat memotivasi siswa dalam membangkitkan keaktifannya dalam menstruktur pengetahuan, serta mampu merespon pembelajaran secara produktif. Model advance organizer juga dapat dibentuk untuk mengajarkan keterampilan-keterampilan pembelajaran yang efektif, salah satunya dengan melibatkan siswa secara langsung dalam pembelajaran.

Model advance organizer memiliki 3 tahap kegiatan, (1) presentasi advance organizer, (2) presentasi tugas atau materi pembelajaran, (3) memperkuat pengolahan kognitif [3]. Tahapan pertama terdiri dari tiga aktivitas; mengklarifikasi tujuan-tujuan pembelajaran, menyajikan advance organizer, dan mendorong kesadaran pengetahuan yang relevan. Tahapan kedua yaitu mempresentasikan materi pembelajaran dalam bentuk ceramah, diskusi, film, eksperimentasi atau membaca. Selama presentasi, pengolahan materi pembelajaran perlu diberikan dengan jelas pada siswa sehingga mereka memiliki seluruh indera petunjuk dan dapat memahami materi dengan baik. Tahapan ketiga adalah melabuhkan materi pembelajaran baru ke dalam struktur kognitif siswa dengan memperkuat kognitif siswa.

Pemanfaatan media teknologi komputer juga dapat diterapkan dalam pembelajaran, khususnya pembelajaran fisika karena dapat mempermudah siswa dalam memahami konsep-konsep fisika yang bersifat abstrak dan susah dipahami siswa. Kemampuan siswa dalam memahami konsep merupakan dasar untuk menyelesaikan masalah, pemahaman mencakup kemampuan untuk menangkap makna dari materi yang dipelajari. Anderson \& Krathwohl [4] menyatakan bahwa "siswa dapat dikatakan memahami apabila dapat merekonstruksi makna dari pesan-pesan setiap pembelajaran, secara lisan maupun tulisan/grafik yang disampaikan melalui pengajaran, buku atau layar komputer. Pemilihan media pembelajaran yang tepat dapat meningkatkan hasil belajar yang optimal. Salah satunya yaitu media pembelajaran macromedia flash yang merupakan sebuah program aplikasi profesional untuk menggambar grafis dan animasi, animasi yang dibuat menggunakan flash dapat berupa animasi vektor atau gambar bitmap [5]. Prinsip kerja macromedia flash berupa penyajian animasi secara visual dalam bentuk tulisan, gambar dan lain-lainnya yang dapat digerakkan berdasarkan konsep yang digunakan dalam pembelajaran.

\section{Metode Penelitian}

Jenis penelitian ini adalah penelitian quasi eksperimen. Sampel dalam penelitian ini adalah 2 kelas, dipilih secara acak dengan teknik cluster random sampling dan terpilih dua kelas sebagai kelas eksperimen dengan model advance organizer menggunakan macromedia flash dan kelas kontrol dengan model pembelajaran direct instruction. Desain penelitiannya berupa two group pretes-postes design. Rancangan penelitian ini ditunjukkan pada tabel 1. 
Tabel 1. Desain Penelitian

\begin{tabular}{cccc}
\hline Sampel & Pretes & Perlakuan & Postes \\
\hline Kelas Eksperimen & $\mathrm{Y}_{1}$ & $\mathrm{X}_{1}$ & $\mathrm{Y}_{2}$ \\
\hline Kelas Kontrol & $\mathrm{Y}_{1}$ & $\mathrm{X}_{2}$ & $\mathrm{Y}_{2}$ \\
\hline Sumber: [6] & & &
\end{tabular}

Keterangan :

$\mathrm{Y}_{1} \quad$ :Pre test

$\mathrm{Y}_{2} \quad$ :Post test

$\mathrm{X}_{1} \quad$ :Perlakuan untuk model advance organizer

$\mathrm{X}_{2} \quad$ : Perlakuan untuk model direct instruction

\section{Hasil Penelitian dan Pembahasan}

\section{Hasil Penelitian}

Pelaksanaan awal dalam penelitian ini adalah dengan memberikan pretes kepada siswa, hal ini bertujuan untuk mengetahui kemampuan awal siswa. Data hasil pretes kelas kontrol dan kelas eksperimen dapat dilihat pada tabel 2.

Tabel 2. Data Pretes Kelas Kontrol dan Eksperimen

\begin{tabular}{ccccc}
\hline \multirow{2}{*}{ No } & \multicolumn{2}{c}{ Kelas Kontrol } & \multicolumn{2}{c}{ Kelas Eksperimen } \\
& Nilai & Frekuensi & Nilai & Frekuensi \\
\hline 1 & 45,00 & 5 & 50,00 & 6 \\
2 & 50,00 & 4 & 55,00 & 7 \\
3 & 55,00 & 6 & 60,00 & 5 \\
4 & 60,00 & 4 & 65,00 & 5 \\
5 & 65,00 & 6 & 70,00 & 4 \\
6 & 70,00 & 3 & 75,00 & 3 \\
7 & 75,00 & 2 & & \\
\hline & Jumlah & 30 & & 30 \\
& Mean & 58,17 & & 64,33 \\
& Std. Deviasi & 9,24 & & 8,38 \\
\hline
\end{tabular}

Data posttest kelas kontrol dan kelas eksperimen dapat dilihat pada tabel 3.

Tabel 3. Data Posttes Kelas Kontrol dan Eksperimen

\begin{tabular}{ccccc}
\hline \multirow{2}{*}{ No } & \multicolumn{2}{c}{ Kelas Kontrol } & \multicolumn{2}{c}{ Kelas Eksperimen } \\
& Nilai & Frekuensi & Nilai & Frekuensi \\
\hline 1 & 55,00 & 3 & 65,00 & 1 \\
2 & 60,00 & 4 & 70,00 & 4 \\
3 & 65,00 & 5 & 75,00 & 5 \\
4 & 70,00 & 5 & 80,00 & 9 \\
5 & 75,00 & 8 & 85,00 & 7 \\
6 & 80,00 & 5 & 90,00 & 4 \\
\hline & Jumlah & 30 & & 30 \\
& Mean & 73,33 & & 80,00 \\
& Std. Deviasi & 10,64 & & 8,41 \\
\hline
\end{tabular}

Berdasarkan tabel di atas, nilai rata-rata posttest kelas kontrol adalah 73,33 dan nilai rata-rata posttest kelas eksperimen adalah 80,00. Hal ini menunjukkan bahwa terjadi peningkatan hasil belajar siswa dan peningkatan pemahaman konsep pada siswa dengan menggunakan model pembelajaran advance organizer menggunakan macromedia flash. Pengujian normalitas dilakukan dengan menggunakan aplikasi SPSS versi 17. Berdasarkan pengolahan data uji normalitas data pretest kelas kontrol dan kelas eksperimen dapat dilihat pada Tabel 4. 
Tabel 4. Hasil Uji Normalitas data Pretest kelas kontrol dan kelas eksperimen

\begin{tabular}{clrrrrrr}
\hline & \multirow{2}{*}{ Kelas } & \multicolumn{3}{c}{$\begin{array}{c}\text { Kolmogorov- } \\
\text { Smirnova }\end{array}$} & \multicolumn{3}{c}{ Shapiro-Wilk } \\
& & Statistic & df & Sig. & Statistic & df & Sig. \\
\hline Nilai & Kelas kontrol & .137 & 30 & .157 & .936 & 30 & .069 \\
pretest & kelas eksperimen & .132 & 30 & .194 & .905 & 30 & .011 \\
\hline a.Lilliefors Significance Correction & & & & & &
\end{tabular}

Pengolahan data uji normalitas data posttest kelas kontrol dan kelas eksperimen dapat dilihat pada Tabel 5.

Tabel 5. Hasil Uji Normalitas data Posttest kelas kontrol dan kelas eksperimen

\begin{tabular}{clrrrrrrr}
\hline & \multirow{2}{*}{ Kelas } & \multicolumn{3}{c}{$\begin{array}{c}\text { Kolmogorov- } \\
\text { Smirnova }\end{array}$} & \multicolumn{3}{c}{ Shapiro-Wilk } \\
& & Statistic & df & Sig. & Statistic & df & Sig. \\
\hline $\begin{array}{c}\text { Nilai } \\
\text { posttest }\end{array}$ & Kelas kontrol & .147 & 30 & .098 & .921 & 30 & .028 \\
\hline & kelas eksperimen & .157 & 30 & .056 & .898 & 30 & .008 \\
\hline a.Lilliefors Significance Correction & & & & & &
\end{tabular}

Pengujian normalitas dengan syarat pengujian jika nilai signifikansi pada kolom kolmogrof-smirnov lebih besar dari 0,05 maka data dianggap berdistribusi normal. Berdasarkan hasil uji normalitas kelas kontrol dan kelas eksperimen terlihat bahwa nilai pretest dan posttest siswa SMA Negeri 3 Bireuen berdistribusi normal. Hal ini dapat dilihat dari kriteria $\mathrm{H}_{0}$ diterima apabila sig $>0,05$.

Setelah melakukan uji normalitas, maka selanjutnya dilakukan uji kesamaan rata-rata nilai pretest. Uji kesamaan rata-rata dilakukan dengan menggunakan aplikasi SPSS versi 17 dengan asumsi kedua taraf signifikan >0,05. Hasil perhitungan uji kesamaan rata-rata dapat dilihat pada Tabel 6 .

Tabel 6. Uji Kesamaan Rata-rata Kelas Kontrol dan Kelas Eksperimen

\begin{tabular}{|c|c|c|c|c|c|c|c|c|c|c|}
\hline & & \multirow{2}{*}{\multicolumn{2}{|c|}{$\begin{array}{c}\text { Levene's } \\
\text { Test for } \\
\text { Equality of } \\
\text { Variances } \\
\end{array}$}} & \multicolumn{7}{|c|}{ t-test for Equality of Means } \\
\hline & & & & \multirow[t]{2}{*}{$\mathbf{t}$} & \multirow[t]{2}{*}{ df } & \multirow{2}{*}{$\begin{array}{c}\text { Sig. } \\
\text { (2-tailed) }\end{array}$} & \multirow{2}{*}{$\begin{array}{c}\text { Mean } \\
\text { Difference }\end{array}$} & \multirow{2}{*}{$\begin{array}{l}\text { Std. Error } \\
\text { Difference }\end{array}$} & \multicolumn{2}{|c|}{$\begin{array}{c}\text { 95\% Confidence } \\
\text { Interval of the } \\
\text { Difference } \\
\end{array}$} \\
\hline & & $\mathbf{F}$ & Sig. & & & & & & Lower & Upper \\
\hline \multirow{7}{*}{$\begin{array}{c}\text { Nilai } \\
\text { pretest }\end{array}$} & Equal & .724 & .398 & -2.708 & 58 & .009 & -6.167 & 2.277 & -10.725 & -1.609 \\
\hline & variances & & & & & & & & & \\
\hline & assumed & & & & & & & & & \\
\hline & Equal & & & -2.708 & 57.4 & .009 & -6.167 & 2.277 & -10.726 & -1.608 \\
\hline & variances & & & & 59 & & & & & \\
\hline & & & & & & & & & & \\
\hline & assumed & & & & & & & & & \\
\hline
\end{tabular}

Berdasarkan Tabel 6, maka terlihat bahwa nilai $\mathrm{F}=0,724$ dengan signifikansi 0,398. Berdasarkan hasil tersebut maka signifikansi lebih besar dari 0,05, sehingga dapat disimpulkan bahwa nilai pretest kelas kontrol dan kelas eksperimen memiliki varians yang sama.

\section{Pembahasan}

Berdasarkan analisis data, terdapat peningkatan pemahaman konsep fisika dengan model advance organizer menggunakan macromedia flash. Hal ini dibuktikan dengan hasil belajar siswa yang meningkat, yaitu berdasarkan perolehan nilai rata-rata pretest siswa kelas kontrol adalah 58,17 dan nilai rata-rata pretest siswa kelas eksperimen adalah 64,33 yang menunjukkan bahwa kemampuan awal kedua kelas hampir sama. Untuk nilai rata-rata posttest kelas kontrol adalah 73,33 dan nilai rata-rata posttest kelas eksperimen adalah 80,00. Hal ini menunjukkan bahwa terjadi peningkatan hasil belajar siswa dan peningkatan pemahaman konsep pada siswa dengan model pembelajaran advance organizer menggunakan macromedia flash. 
Togi, dkk [7] menemukan bahwa setelah pemberian tindakan pada siklus I, tingkat kemampuan komunikasi matematis siswa meningkat menjadi 64,14 dengan jumlah siswa yang mencapai KKM sebanyak 12 orang $(40 \%)$ dari jumlah siswa. Setelah pemberian tindakan siklus II, rata-rata kemampuan komunikasi siswa meningkat menjadi 78,75 dengan jumlah siswa yang mencapai KKM sebanyak 26 orang (86,67\%) dari jumlah siswa. Berdasarkan uraian diatas dapat disimpulkan komunikasi matematis siswa meningkat dengan menerapkan model advance organizer berbantuan macromedia flash pada materi program linear.

Tasiwan, dkk [8] dalam penelitiannya menyimpulkan bahwa siswa mengalami peningkatan kemampuan analisis - sintesis dalam aspek menguraikan, mengkategorikan, mengidentifikasi, merumuskan pernyataan, merekonstruksi, menentukan konsep, dan menganalisis konsep dengan rata-rata peningkatan delta skor sebesar $54,46 \%$, uji t sebesar 6,4, dan skala gain sebesar 0,3. Hatika [9] dalam penelitiannya menyimpulkan bahwa hasil analisis daya serap dalam kategori baik, ketuntasan belajar secara klasikal sudah tuntas dan efektivitas pembelajaran adalah efektif. Ini berarti bahwa penggunaan model advance organizer berbantu animasi komputer adalah efektif digunakan dalam melihat hasil belajar fisika siswa SMA Rambah Hilir baik ditinjau melalui daya serap, ketuntasan belajar dan efektivitas pembelajarannya.

Putriana [10] dalam penelitiannya menyimpulkan bahwa pembelajaran menggunakan model advance organizer dapat meningkatkan keterampilan berpikir kritis dan pemahaman konsep siswa dibandingkan metode konevensional. Pratitis [11] dalam penelitiannya menyimpulkan bahwa model pembelajaran advance organizer berpengaruh positif terhadap peningkatan penguasaan konsep kimia pada materi larutan penyangga.

\section{Kesimpulan}

Berdasarkan hasil analisis data secara umum didapatkan bahwa pemahaman konsep siswa sesudah pembelajaran melalui penerapan model advance organizer menggunakan macromedia flash lebih baik daripada sebelum pembelajaran. Maka dapat disimpulkan bahwa pemahaman konsep siswa melalui penerapan model pembelajaran advance organizer menggunakan macromedia flash dapat meningkatan pemahaman konsep siswa kelas XI SMA Negeri 3 bireuen.

\section{Ucapan Terimakasih}

Selama penyusunan artikel ini penulis telah banyak mendapatkan konstribusi dari berbagai pihak, baik secara langsung maupun tidak langsung, terutama kepada pihak sekolah SMA Negeri 3 Bireuen yang telah memberikan kesempatan kepada penulis untuk melakukan penelitian di tempatnya. Penelitian ini tidak akan berjalan lancar tanpa adanya konstribusi dari berbagai pihak. Maka, penulis mengucapkan terima kasih yang sebesar-besarnya.

\section{Kepustakaan}

[1] Ataha, An Investigation Of Scientific Attitude Among Students In Senior Secondary Schools In Edo South Senatorial, Journal of Education and Practice. Volume 4, 2013.

[2] Young, Hugh D. \& Roger A. Freedman, Fisika Universitas Edisi Kesepuluh. Jakarta: Erlangga, 2002.

[3] Joyce. B. dkk, Model of Teaching (Model-Model Pengajaran) edisi kedelapan. Yogyakarta: pustaka pelajar, 2009.

[4] Anderson, O.W \& Krathwohl, D. R. A, Taxonomy for Learning, Taeaching, and Assesing: A Revision of Bloom's Ttaxonomy of Educational Objectives. The Addison.Wesley Longman, Inc, 2001.

[5] Ramadhan, A, Seri Pelajaran Komputer Macromedia Flash MX. Jakarta: PT Elex Media Komputindo., 2004.

[6] Sugiyono. Metode Penelitian Kuantitatif, Kualitatif dan R\&D. Bandung: Afabeta. 2011.

[7] Togi. dkk, Implementasi Model Pembelajaran Advance Organizer Berbantuan Macromedia Flash Untuk Meningkatkan Kemampuan Komunikasi Matematis Siswa Kelas IX SMA PAB Saentis. Jurnal Inspiratif. FMIPA:Unimed, 2017.

[8] Tasiwan. dkk, Pengaruh Advance Organizer Berbasis Proyek Terhadap Kemampuan Analisis-Sintesis Siswa, Jurnal Pendidikan Fisika Indonesia (JPFI), 10(2014): 1-8, 2014.

[9] Hatika. R.G, Peningkatan Hasil Belajar Fisika Dengan Menerapkan Model Pembelajaran Advance Organizer Berbantu Animasi Komputer, Jurnal Pendidikan Fisika Indonesia (JPFI), 12(2), 2016: 113-117.

[10] Putriana. I. dkk, Penerapan Model Pembelajaran Advance Oerganizer Untuk Meningkatkan Pemahaman Knsep dan Keterampilan Berpikir Kritis Siswa pada Materi Fluida Dinamis di SMAN 5 Banda Aceh. Proseding Seminar Nasional Pascasarjana (SNP), April 13, 2017. 
[11] Pratitis. I, Binajda, Achmad, Penerapan Model Pembelajaran Advance Organizer Bervisi Sets Terhadap Peningkatan Penguasaan Konsep Kimia. Jurnal Inovasi Pendidikan Kimia, Vol 8, No.2, 2014, hlm 1370-1379. 